\title{
STRUCTURAL MEASURES AGAINST FLOODS ON THE SPANISH MEDITERRANEAN COAST. EVIDENCE FOR THE PERSISTENCE OF THE "ESCALATOR EFFECT"
}

\author{
ALFREDO PÉREZ-MORALES*, MARÍA ASUNCIÓN ROMERO-DÍAZ, \\ SALVADOR GIL-GUIRADO
}

Department of Geography, University of Murcia, Campus de la Merced, 30001 Murcia, Spain.

\begin{abstract}
The risk of flooding on the Spanish Mediterranean coast is a constant threat whose importance has progressively increased in recent decades despite the enormous efforts made to mitigate it. Of the two strategies practiced to reduce the effects of this danger, structural measures have prevailed to a great degree over nonstructural ones during this period of increased risk. Here, these works carried out from the beginning of the 20th century to the present are cataloged, with a double objective: (i) to show the evolution of the number of infrastructures, their typology, and their distribution on the Mediterranean coastline; and (ii) to evaluate whether the basins with and without a dam have followed differing trends in the occupation of floodplains to show the persistence of the "escalator effect". The results obtained indicate that there is no statistically significant difference between the occupation of the floodplainsby basins with and without a dam for the Return Periods (RP) 50, 100, and 500 years. However, for RP10, there is a higher occupation by basins with a dam.
\end{abstract}

\section{Actuaciones estructurales contra inundaciones en el litoral mediterráneo español. Evidencias de la persistencia del "escalator effect"}

RESUMEN. El riesgo de inundación en el litoral mediterráneo español es una constante cuya importancia ha ido aumentando progresivamente en las últimas décadas a pesar de los enormes esfuerzos realizados para mitigarlo. De las dos estrategias practicadas para reducir los efectos de este peligro, las acciones estructurales han prevalecido en gran medida sobre las no estructurales durante este período de mayor riesgo. En este trabajo se catalogan las actuaciones en funcionamiento con un doble objetivo: (i) mostrar la evolución del número de infraestructuras, su tipología y su distribución en el litoral mediterráneo; y (ii) evaluar si las cuencas con y sin presa han seguido diferentes tendencias en la ocupación de las llanuras aluviales para evidenciar la persistencia del "escalator effect". Los resultados obtenidos indican que no existe diferencia estadísticamente significativa entre la ocupación de las planicies aluviales por cuencas con y sin presa para los Períodos de Retorno (PR) 50, 100 y 500 años. Sin embargo, para PR10, hay una mayor ocupación por cuencas con presa.

Key words: Risk of flooding, structural measures, perception, escalator effect, Spain.

Palabras clave: Riesgo de inundación, actuaciones estructurales, percepción, “escalator effect”, España. 
*Corresponding author: Alfredo Pérez-Morales, Department of Geography, University of Murcia, Campus de la Merced, 30001 Murcia, Spain. E-mail address: alfredop@um.es.

\section{Introduction}

The scientific approach and formulas against the hazards of flooding have evolved substantially in recent years, from a technocratic and applied position of responding to problems to a more social one. According to Smith and Petley (2009), four major stages can be seen that have marked the changes in the structural strategy. In the first place, until 1950, all the effort and attention were dedicated to the technological capacity, and the construction of large infrastructures was the only solution to mitigate natural hazards, especially those of hydrometeorological origin. This stage was followed by another of a behavioral nature in which, in the face of evidence of increased economic losses associated with disasters, emergency management gained ground. The third stage began in the 1970s. Some scientific studies (White, 1958, 1973; Montz and Gruntfest, 1986) show convincing results that reveal the limited effectiveness of structural measures to stop the increase in economic losses associated with the floods and the need to reflect on and reformulate the way to tackle the danger. Later work, such as that of Parker (1995), tried to respond to this trend and concluded that the false sense of security derived from said engineering measures would only have increased the risk exposure, since it encouraged the occupation of floodplains that until then had not been altered by humans. This social process has been given different names: escalator effect (Parker, 1995), paradox of safe development (Burby, 2006), or leveé effect (Lane et al., 2011). A fourth stage commenced when we became aware of the above and prevention began to gain prominence in the scientific world, in the late 1980s and early 1990s, with the declaration of the International Decade for Natural Disaster Reduction proclaimed by the United Nations. Unfortunately, the measures taken by administrations are generally subject to delays and so floods force them to make use of specific measures such as channels and storm tanks installation.

The Spanish Mediterranean watersheds, the object of the present work, are a good example of the aforementioned process. Here, floods represent the most frequent danger of natural origin, due, to a great extent, to the impact of flash-flood episodes - such as those that have recently affected urbanized areas (Berz et al., 2001; Jonkman, 2005). This should be more than enough evidence to realize that any strategy based on risk management and derived from technical measures to control danger will not be effective in reducing losses. However, the problem is more complex than it seems to be and, to a large extent, it is related to the degree of perception of hazard and the purpose of the measures already mentioned.

When a flood occurs with catastrophic results, the affected population immediately notices a lack of security and equally quickly demands structural measures to solve the problem. Historically, this situation has been increasingly repeated in societies where population pressure and urbanization positively correlate with the increase in floods, so much so that significant resources have been allocated with the intention of mitigating the risk of flooding. Examples of defense plans against flooding include the Segura Basin (southern Spain) (Lemeunier and Picazo, 1988), the diversion of the mouth of the Turia River as it passes through the city of Valencia (Spain), the Dutch embankment program (Wesselink, 2007), in Pakistan (Tariq and Van De Giesen, 2012), and those in the USA (Galloway, 2004).

Considering the trend of the losses caused by this type of episode (Gil-Guirado et al., 2019), and regardless of their accentuation over time due to climate change (Quereda, 2000; Djalante, 2019), solutions based on structural measures seem to be insufficient since the exposure to the flooding hazard has not stopped growing (Pérez-Morales, 2008; Pérez-Morales et al., 2015; López-Martínez et al., 2020). Works on the subject (Saurí et al., 2001; Calvo García-Tornel and Granell Pérez, 2009; Saurí et al., 2010) seem to reach the same conclusion as Parker regarding this cognitive dissonance. That is, the construction of a dam has the same effect on the perception of the population as the temporal distancing of a flood episode; thus, the danger is apparently obviated or considered controlled, with the consequent reckless management response and the occupation of areas bordering the riverbed, reinforced by the 
false sense of security generated by said infrastructures. The foregoing leads us to question whether a similar trend has truly been experienced in our study area and, indirectly, if there is a different perception among the population that occupies those basins without a dam, with respect to those that do have a dam, to determine if the "escalator effect" suggested by Parker and Tapsell (2009) persists.

Based on all the above, the objectives proposed for this work were the following: (i) to catalog, geolocate, and date the structural measures aimed at mitigating the risk of flooding on the Spanish Mediterranean coast that are working, and (ii) to determine if a significant difference exists between the hydrographic basins regulated by dams and those that are not, in the trend followed in the occupation of floodplains from the construction of a dam to the present.

\section{Study area}

The study area includes the basins and sub-basins that drain the municipalities of the Spanish Mediterranean coast between the Region of Murcia and Catalonia (Fig. 1). For reasons already well studied (Giménez, 2003 and Olcina-Cantos, 2004), since the 1960s, this area has become one of the main tourist destinations in the world, with one of the highest rates of population and construction growth in Europe - unfortunately, to a large extent, in an uncontrolled way (Vera-Rebollo, 2005). This uncontrolled process of land occupation led to a series of environmental tolls, including an increase in the number of floods. Regardless of the materialization or not of the projected trends of climate change, the waterproofing and sealing of the soil in the Mediterranean area, experienced during all those years (Añó Vidal et al., 2005; Valera Lozano et al., 2011; Pérez Morales et al., 2016), played a determining role in this exponential increase in flood events. The answer to such problems has been forged over time in such a way that, today; the technology-based solution continues to prevail over adaptation and prevention.

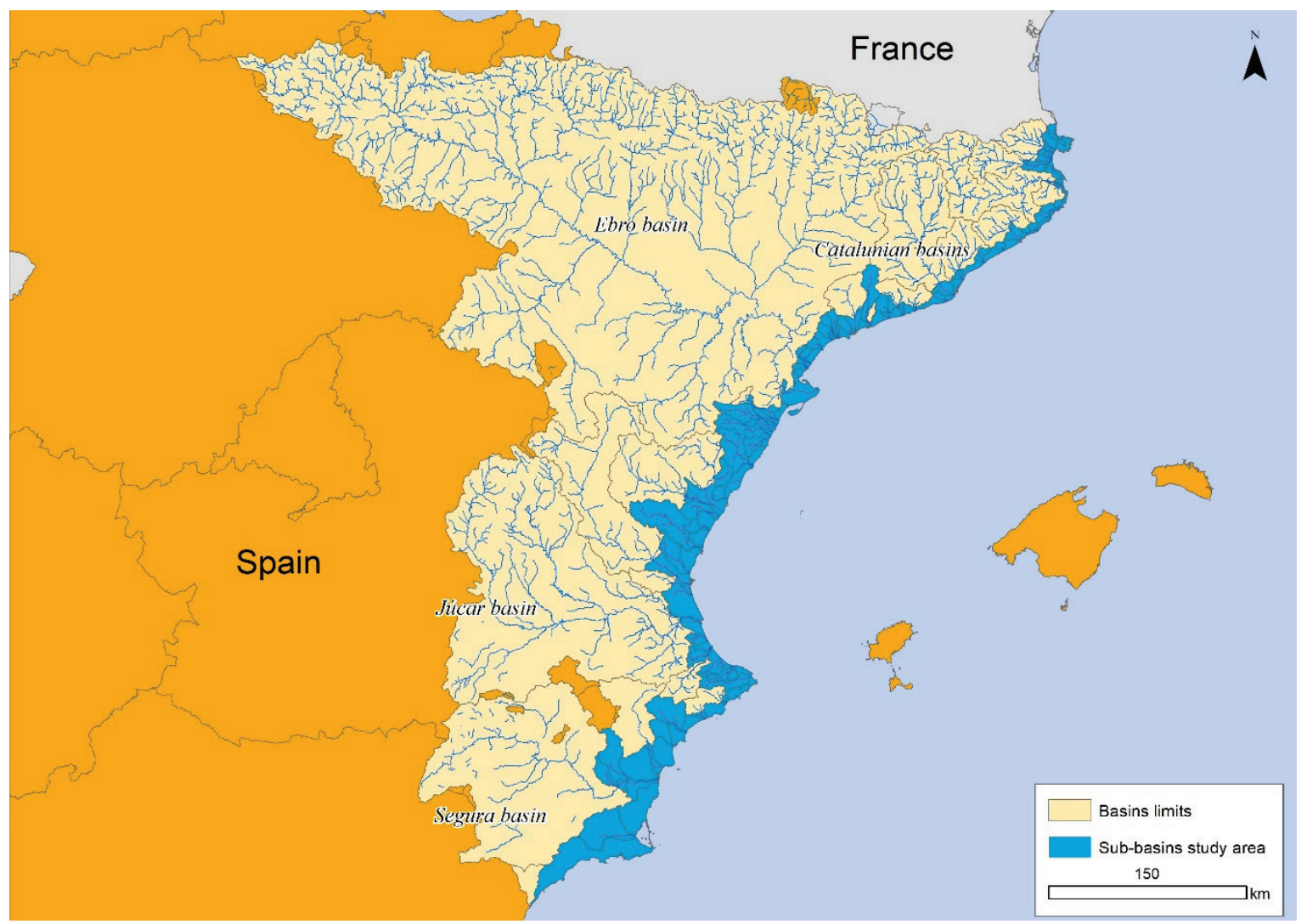

Figure 1. Location of the study area (Source: own elaboration). 
The afore mentioned sequence that led to the current state of taking structural measures to control floods began with the process of modernization of the country and the demographic growth experienced during the 20th century. The second phase of the demographic transition in Spain was followed by the consequent occupation of new spaces, mostly for agricultural use, which inexorably caused an increase in both the demand for water resources and the territories affected by the risk of flooding. To tackle both issues, and taking into account the technological advances achieved up to that timeas well as the 19th-century experiences of the first large dams in the rivers of the Peninsula (Gil Olcina, 1992, 2002), strategies based on structural measures were implemented to mitigate the violent flood waves that flowed through the riverbeds and, at the same time, to retain flows for use as drinking water or irrigation, mainly during periods of low water supply. The result was a firm commitment at the state level to these defensive infrastructures and at the beginning of the 20th century the "Progress of a General Plan for Swamps and Irrigation Canals" was published, aimed at solving the irregularity of the river regimes through the construction of reservoirs with sufficient dimensions. According to this document, practically all these types of works had to assume the double purpose of laminating flood and regulating flows, allowing the establishment of reserves.

The technological approach was consolidated in the times of Primo Rivera and with the failed projects of the Second Republic (Pérez-Morales, 2009). In those years, the regenerationist ideas that penetrated the heart of Spanish society in response to the crisis of the late 19th century found their maximum expression in the creation of the hydrographic confederations. The principle of the use and integral defense of the basin of a main river was then accepted. These two concepts became irretrievably inseparable from the moment that a commitment was made to the construction of reservoirs as hydraulic works for the control and regulation of the flows circulating through Spanish rivers.

Since then, the number of structural measures has continued to grow, the maximum defense capacity being reached at the end of the 1970s with regard to dams (Córdova, 2008). Unfortunately, registries such as the Consorcio de Compensación de Seguros (CCS, 2018) and data bases such as: Carmona and Ruíz (2000) in Comunitat Valenciana; Romero-Díaz and Maurandi-Guirado (2000), Castejón-Porcel and Romero-Díaz (2014) in Region of Murcia, Llasat and Barriendos (2005) in Cataluña, and Gil-Guirado and López-Martínez (2019) in the Mediterranean Spanish coast, show that the problem, far from being solved, has worsened over time as the exposure to flooding has increased. In recent years it has become clear that, despite having a costly system of regulation and defense (without completely underestimating its effectiveness), every time a flood occurs, confederations and regional and local administrations are forced to respond through infraestructures (channeling and storm tanks) that have the sole purpose of amending the situation by patching-up the defensive system until another episode takes place.

\section{Sources and methodology}

To achieve the objectives of this work, a two-step sequential procedure was carried out. First, the database of the structural measures of the study area was configured. For the cataloging, localization, and dating of these actions, a search was made for three types of infrastructure that have been built and are in operation: dams, channeling, and storm tanks. The variables that make up the database are:

- Id: the identification number of each of the structural measures.

- Type of action: the following infrastructures were selected for the study: dams, channeling, and storm tanks.

- Name of the action: the official name of each of the infrastructures.

- Coordinates $(\mathrm{x}, \mathrm{y})$ in ETRS89 format, for georeferencing the structural measures.

- Year of construction: the year of completion of each of the works was taken as a reference. 
- Status: the current situation of the infrastructure, whether or not it is in use or under construction.

- Municipality: the municipality in which the action is located.

- Channel: the channel on which the infrastructure has been built, or the channel that feeds it with its waters.

- Basin: the hydrographic basin to which it belongs.

- Capacity: the maximum storage capacity allowed by the infrastructure (in the case of dams and storm tanks).

The consultation procedure followed to compile all this information used primary and secondary sources (see Table 1). Regarding the former, a temporal analysis of aerial orthophotos from different flights over the study area $(1956,1981,2002,2016)$ was carried out. Through photointerpretation, different easily perceptible actions such as channels or dams were compiled. Once those identified through secondary sources had been discounted, the year of construction was revealed by specifically consulting digital files, press releases, or contrasting aerial orthophotos from different years, with the intention of determining as accurately as possible when they were carried out. The viewers used for the photointerpretation were: The Territorial Information System (https://sitmurcia.carm.es/); National Plan for Aerial Orthophotography (PNOA) (https://pnoa.ign.es/); Valencian Spatial Dades Infrastructure (http://idev.gva.es); Fototeca (https://fototeca.cnig.es/); Instituto Geológico y Cartográfico de Cataluña (https://www.icgc.cat/es/); and Instituto Cartográfico Valenciano (http://www.icv.gva.es/va/). The results obtained with this methodology made it possible to identify, and date the years of construction of 25 structural measures that did not appear in the secondary sources.

Regarding the search carried out in secondary sources, the following were consulted:

- National System for Flooding Zones Cartography (SNCZI in Spanish) of MAGRAMA (Ministry of Agriculture, Food and Environment). This tool, developed as part of the application of the European Directive 2007/60 on the evaluation and management of floods, incorporates the inventory of dams and reservoirs in Spain. In it, one can consult the geographical location, data on the basin, reservoir capacities, status of the security documents, technical data, photographs, and plans of the dams.

- Database of the Society of Dams and Reservoirs (SEPREM). This institution has a web service that provides information on these infrastructures, such as the year of construction and the capacity.

- Inventory of Spanish Dams. Spanish National Committee for Large Dams (SPANCOLD).

- Official information from Hydrographic Confederations, obtained by exhaustive searches in their geographic information viewers. The geographic information viewer of the Segura Hydrographic Confederation (CHS in Spanish) offers great possibilities when it comes to obtaining information, since it has a spatial database dedicated to infrastructures. In it, one can find data on dams and reservoirs, as well as on more specialized infrastructure when looking for more measures. The Júcar Hydrographic Confederation (CHJ in Spanish) offers practically the same service as the CHS; however, it should be noted that, on its website, the CHJ has information on the actions carried out in the Júcar basin, such as the technical files on the infrastructures built. This provided data on the location and specific details of each of them for the present work. Likewise, for this same demarcation, information was compiled on the actions planned as of 2003 according to the Territorial Action Plan of a sectoral nature on the Prevention of Flood Risk in the Valencian Community (PATRICOVA) (GV, 2003). The Ebro Hydrographic Confederation (CHE in Spanish) also has a cartographic viewer that provides 
information on dams and reservoirs, in addition to some actions carried out, although not of a structural nature. The present study focused on the eastern part of the Ebro basin in the area closest to the Mediterranean Sea: the province of Lleida and the delta in the south of Tarragona. Regarding Catalonia, the consultation of the Catalan flood plan (INUNCAT) (GC, 2010) was also useful, since it offers data on infrastructure projects for defense against floods. The Catalan Water Agency (ACA in Catalan) was also consulted, yielding a list of numerous channelings for which it was necessary to complete the work with photointerpretation and geolocation.

- The last of the secondary sources was a bibliographic review of research articles and books, to complete the information on an action or find evidence of works not previously identified. Some of the most important publications are: Segura basin, Grindlay and Hernández, 2007, PérezMorales, 2008; in Júcar basin, Marco, 2012.

Table 1. Summary table of consulted sources (Source: Own elaboration).

\begin{tabular}{|c|c|c|c|}
\hline Name & Source & Primary/secondary & Year \\
\hline Orthophotos & 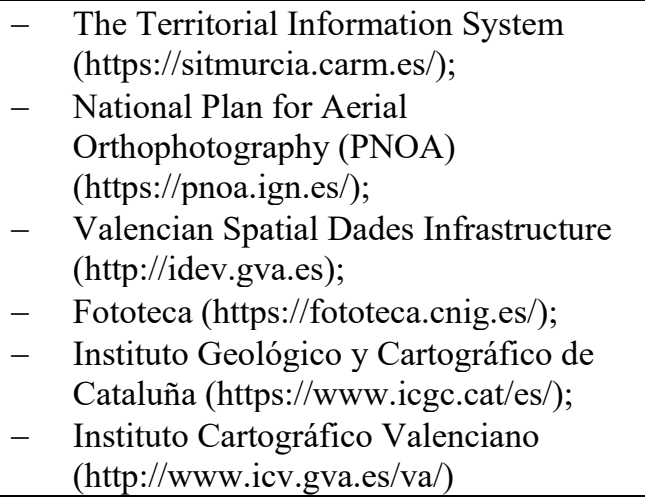 & Primary & $\begin{array}{l}\text { 1956-1957; } \\
\text { 1973-1986; } \\
\text { 1980-1986; } \\
\text { 1997-2003; } \\
\text { 2004-2019 }\end{array}$ \\
\hline $\begin{array}{l}\text { National System for } \\
\text { Flooding Zones } \\
\text { Cartography (SNCZI) }\end{array}$ & $\begin{array}{l}\text { MAGRAMA (Ministry of Agriculture, Food } \\
\text { and Environment) }\end{array}$ & Secondary & 2015 \\
\hline $\begin{array}{l}\text { Database of the Society } \\
\text { of Dams and } \\
\text { Reservoirs. }\end{array}$ & Society of Dams and Reservoirs (SEPREM) & Secondary & 2020 \\
\hline $\begin{array}{l}\text { Geographic } \\
\text { information viewers }\end{array}$ & $\begin{array}{ll}- & \text { Segura Hydrographic Confederation } \\
\text { (CHS in Spanish); } \\
\text { - } \quad \text { Júcar Hydrographic Confederation } \\
\text { (CHJ in Spanish) }\end{array}$ & Secondary & 2020 \\
\hline $\begin{array}{l}\text { Territorial Action Plan } \\
\text { of a sectoral nature on } \\
\text { the Prevention of Flood } \\
\text { Risk in the Valencian } \\
\text { Community } \\
\text { (PATRICOVA) }\end{array}$ & Generalitat Valenciana & Secondary & 2003 \\
\hline $\begin{array}{l}\text { Catalan flood plan } \\
\text { (INUNCAT) }\end{array}$ & Generalitat de Catalunya & Secondary & 2010 \\
\hline $\begin{array}{l}\text { Inventory of Spanish } \\
\text { Dams. Spanish } \\
\text { National Committee } \\
\text { for Large Dams }\end{array}$ & $\begin{array}{l}\text { Comité Nacional Español de Grandes Presas. } \\
\text { SPANCOLD }\end{array}$ & Secondary & $\begin{array}{l}1970,1973, \\
1986,1991, \\
2006\end{array}$ \\
\hline $\begin{array}{l}\text { Bibliographic review } \\
\text { of research articles and } \\
\text { books }\end{array}$ & $\begin{array}{l}\text { Grindlay and Hernández, 2007, Pérez- } \\
\text { Morales, 2008; Dios, 2008; Marco, } 2012 .\end{array}$ & Secondary & $\begin{array}{l}2007,2008, \\
2012\end{array}$ \\
\hline
\end{tabular}


The second step of the methodology combined through spatial analysis with a GIS the database of structural measures with the parcels of the cadastre (MHAP, 2020) and the flooded areas of each of the SNCZI return periods, both in vector format. For this, the procedure proposed by Pérez-Morales et al. (2015) was used. Firstly, the cadastral parcels were associated with the hydrographic sub-basins of the study area in which they are found, through the spatial joint geoprocess. Subsequently, the cadastral parcels likely to be affected in the flooded areas of each of the return periods were identified through a selection of parcels based on their location in the flooded areas. Once this spatial database had been prepared, the years of construction of the cadastral parcels and the dams were listed. In this way, the year from which the sub-basins of the study area began to be regulated was identified and the percentage increases in cadastral parcels registered from the year following the start-up of each dam could be evaluated. Finally, a database was obtained that allowed us to evaluate the urban growth experienced in basins with and without a dam and to test the starting hypothesis.

\section{Results}

Figure 2 represents the 300 structural carried out in the period 1594-2016 and which are still in operation. From its analysis, several issues emerge. First, there are two well differentiated stages that confirm what has already been pointed out by Smith and Petley (2009). In the first, it was attempted to control the water resources for the human supply, irrigation, and hydroelectric production by means of large public works in the form of dams (Fig. 2a). In the second, since the end of the 1980s, where an accentuation can be seen, unprecedented defensive actions due to the increase in catastrophic flood events were performed (Quevedo, 1963; Mateu, 1990; Berga, 1997, 2003; Olcina-Cantos and Rico Amorós, 1999; Pérez-Morales, 2010) motivated by unorganized processes of transformation and occupation of the territory that were experienced in previous decades (Olcina-Cantos et al., 2016) (Fig. $2 b)$. For all the Spanish hydrographic basins, these actions had administrative and legal support when the Regulation of the Public Administration of Water and Hydrological Planning was approved (BOE, 1988). In these state regulations, reduction of the vulnerability to flooding was considered one of the main objectives (Olcina-Cantos, 2007).
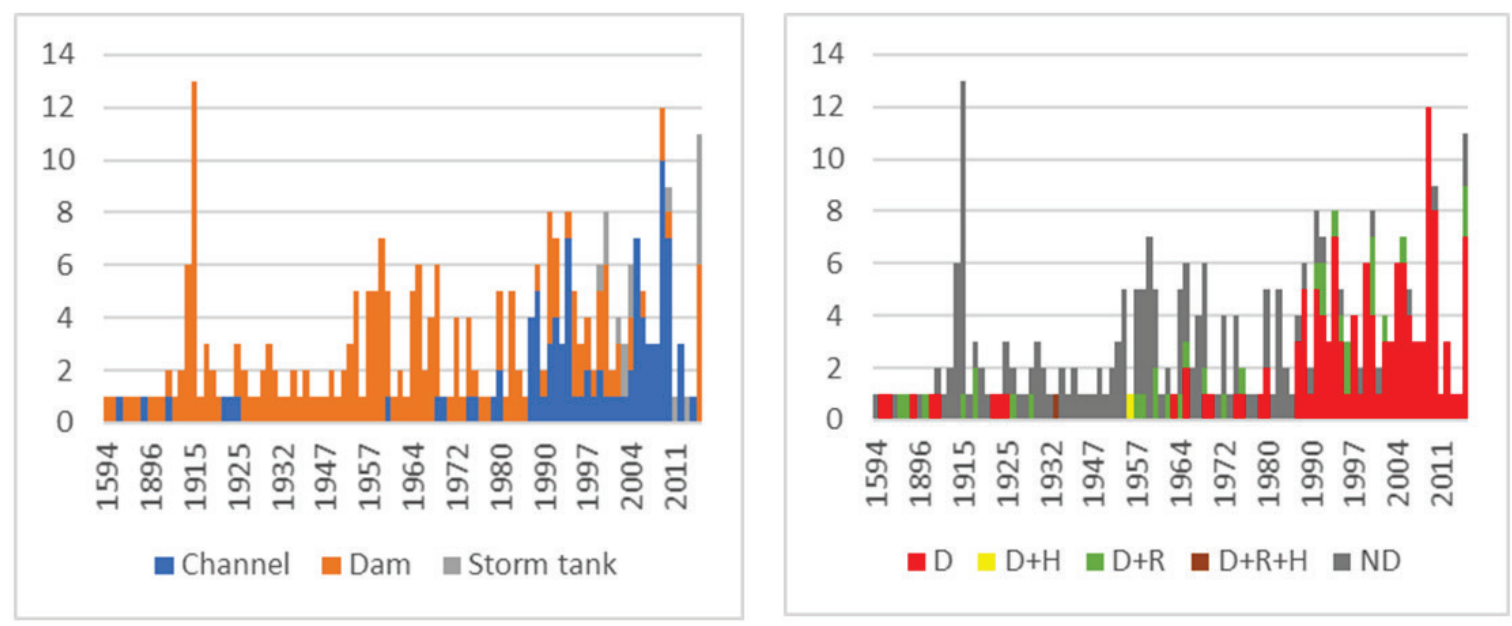

Figure 2. Evolution of the number of structural measures in the study area by type (a) and by use dedicated to defense and other purposes (b). Legend: D: Defense; D+H: Defense and Hydroelectric; D+R: Defense, Resource, and Hydroelectric; Not dedicated to defense (Source: Database).

In Figure 3 we can see a spatial distribution of the structural measures carried out in the study area. A higher density is observed in the rivermouth areas than upstream. As has already been pointed out, most of these coastal nuclei have undergone very rapid growth over the last few years that has motivated the creation of an important network of channeling to be able to safely integrate the 
hydrographic network into the urban area. A similar process has happened with the creation of storm tanks, which, being more recent devices, did not begin to be used as a solution until the end of the 20th century.

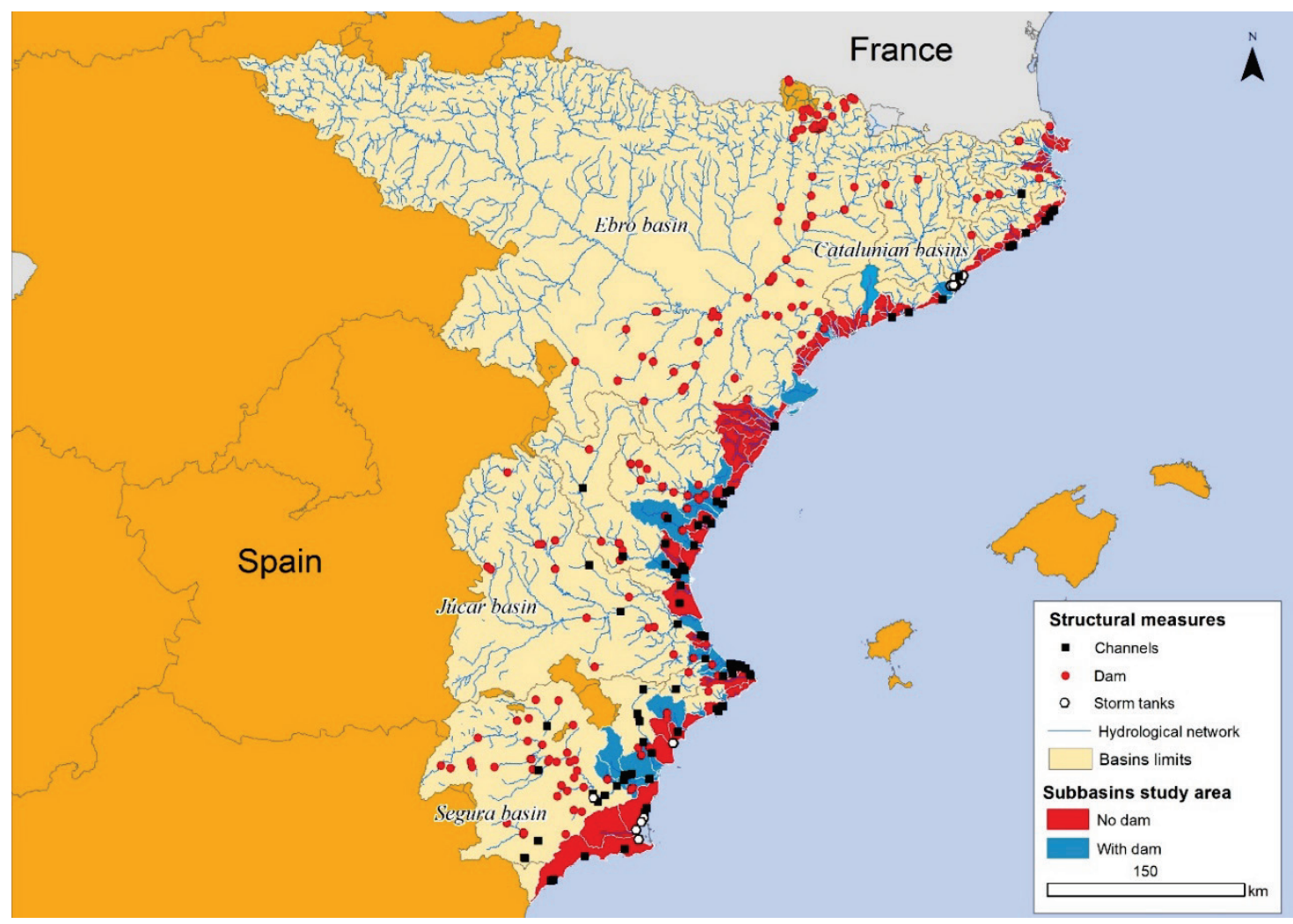

Figure 3. Distribution map of the structural measures (Source: Database).

\subsection{Dams and reservoirs}

The fluvial regime associated with the dynamics of the Mediterranean climate leads to long periods of low waterflow, suddenly interrupted by large flood events. Despite these dynamics being completely natural, demographic pressures and activities derived from this growing population urgently demand this type of expensive infrastructure in order to solve the risks of drought and flooding. The evolution since the construction of the first dam in Spain (1594, Tibi, Alicante) has been subject to periods of both firm support for these infraestructures and complete hostility (Gil Olcina, 2002; PérezMorales, 2009). On the purpose and constructive trend of dams in Spain, the bibliography (Córdova, 2008) indicates that they have gone from seeking only the regulation of channels through reservoir construction to overcoming periods of drought and having permanent water resources with which to irrigate, to a final stage in which the viability of reservoirs for irrigation is questioned and reservoir and hydroelectric production remain as the only justification for their construction. The afore mentioned can be seen in Figure 4.

However, although the trend seems stable, several factors could change it: the increasingly complicated task of finding suitable places to build dams, the Water Framework Directive, which is committed to quality rather than quantity, the commitment to desalination after the repeal of the National Hydrological Plan, environmental pressure, and the economic crisis of 2008 that drained resources for public works have been a perfect storm for these projects.

From a spatial point of view (Fig. 5), it should be noted that some of the flood-control reservoirs are located far from the coast because their construction directly conditions the downstream regions that 
are in the same basin. An example of this are the structural measures carried out in Castilla-La Mancha and Aragon. The effectiveness of flood control dams declines as their distance from the population centers to be protected increases. There are two reasons for this: the possibility of flooding in unregulated areas and the loss of lamination as the distance downstream increases (Ayala, 2002).

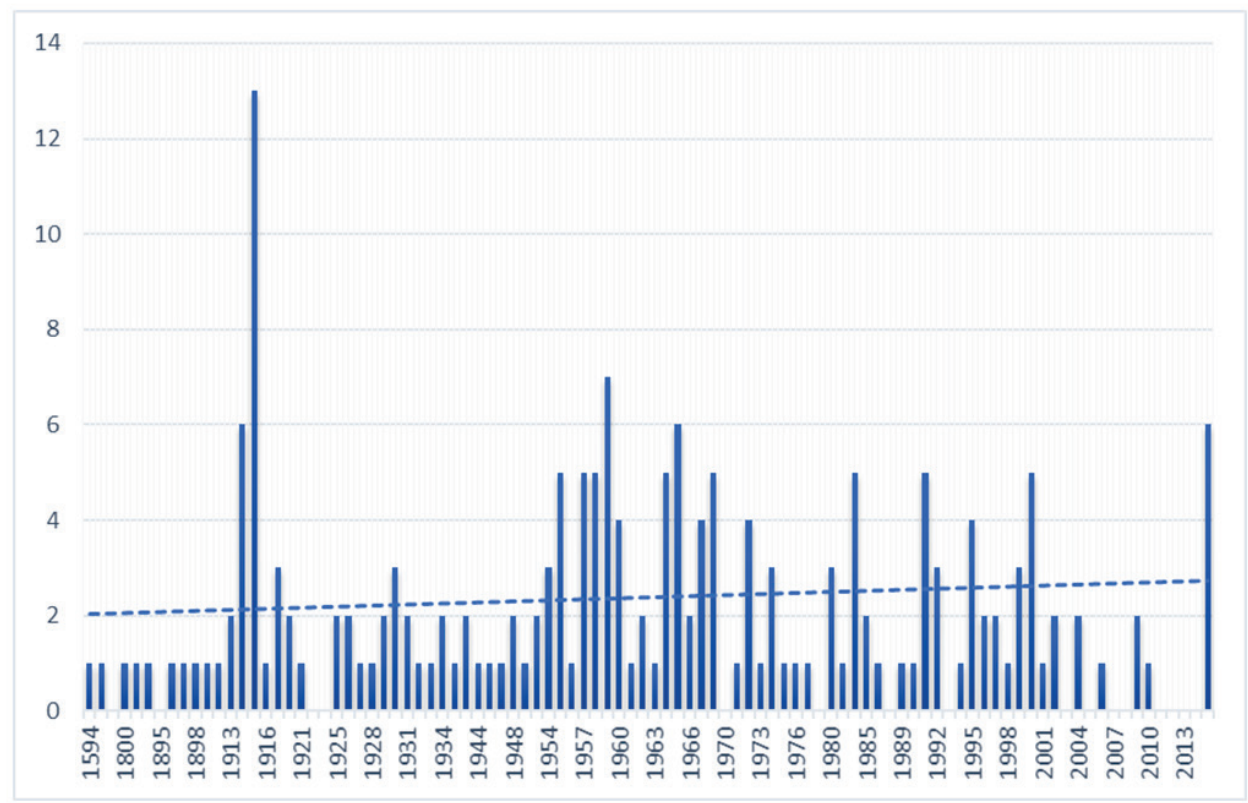

Figure 4. Evolution of dams and reservoirs (1594-2016) (Source: Own elaboration).

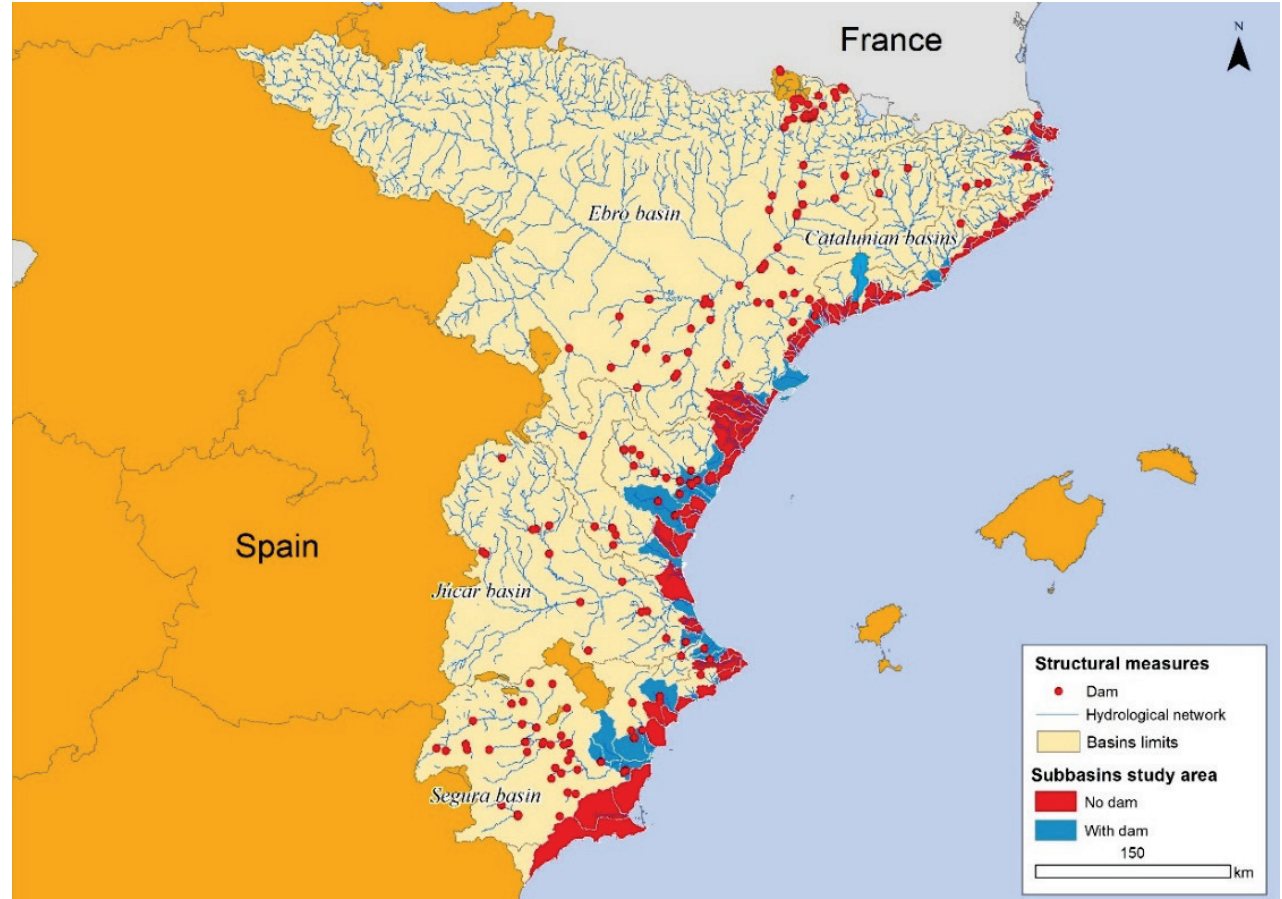

Figure 5. Map of the distribution of dams that affect the sub-basins of the study area. (Source: Own elaboration).

\subsection{Channeling}

Channeling has shown constant growth up to the present time (Fig. 6). As has already been pointed out, since the 1990s this type of artificial channel modification has been the preferred action of 
regional and local administrations to improve the drainage and defense of flood prone areas that have been progressively occupied in coastal municipalities. It could be said that administrations have found, in this type of work, the fastest and cheapest way to respond to the problems posed by the progressive ocupation of riverbeds due to their lack of management.

In relation to this trend, a part of society has called loudly for the establishment of a new relationship between rivers and the population through the replacement of traditional infrastructures by others that respect the fluvial environment. This implies that flood prevention should be compatible with the construction of infrastructures that favor the return of channels to their most natural state possible. However, although this movement is trying to impose itself in today's society, seeking a change in the management of hydraulic policy and the risk of flooding, the data collected show that conventional hydraulic infrastructures continue to be the option that is mostly chosen in areas where, until now, little has been done in terms of controlling the forces that increase vulnerability; fundamentally, urban growth (Roset-Pàges et al., 1999) (Fig. 7).

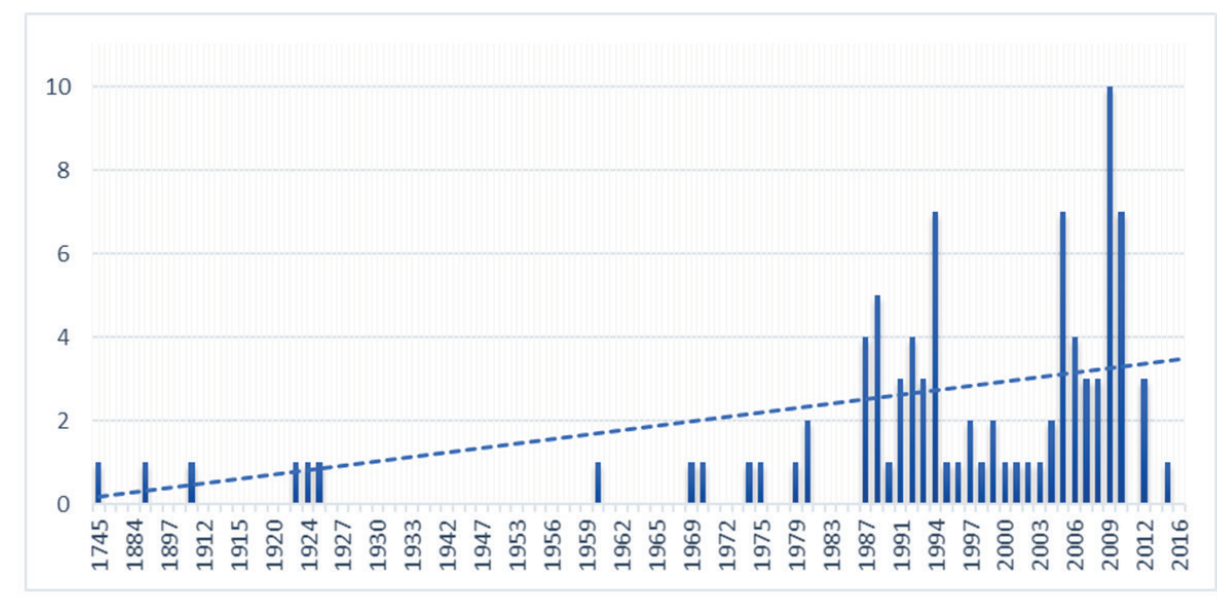

Figure 6. Evolution of channeling (1745-2016) (Source: Own elaboration).



Figure 7. Channeling distribution map (Source: Own elaboration). 


\subsection{Storm tanks}

Storm tanks, also known as spillways, are sewerage infrastructures consisting of a tank dedicated to capturing and retaining the rainwater transported to it by the collectors, especially when there is very intense rainfall, to reduce the possibility of flooding in the cases in which the drainage capacity of the water is less than the volume of rain. These tanks also have a pre-purification function by preventing the first rainwater - the most polluted because, although the rain is very clean, it produces a washing of the asphalt- from being dumped directly into natural aquatic systems such as rivers. Instead, wastewater treatment is carried out so that, once it is decontaminated, the water can be discharged into streams or bodies of water for later use.

These devices designed to laminate the maximum flows of an avenue are particularly important in areas where there has been massive waterproofing of the basins (Lessard and Beck, 1991; AndrésDoménech et al., 2012; Ayesa, 2016). A good example of the above can be found on the East coast of the Autonomous Community of the Region of Murcia. In the immediate populations, this device was chosen with the dual objectives of reducing floods effects and decanting pollutants in the form of fertilizers and pesticides generated by intensive agriculture and that are responsible for the ecological disaster of the Mar Menor (Perni and Martínez-Paz, 2013; Pérez-Morales et al., 2016).

As can be seen in Figure 8, the first storm tank in the study area was built in 1999 (Gago, 2010); therefore, it can be considered as a recent solution. Since then, the proliferation has been constant and these actions have been gaining importance, in both number and dimensions, within what are known as sustainable urban drainage systems (SUDS) (Castro et al., 2005).

The location map (Fig. 9) shows how these infrastructures are located at river mouths, mostly on the coast. In Barcelona there are nine, distributed throughout the city, that try to solve the drainage problems of the city. The province of Alicante has two storm tanks; the first was inaugurated in 2011 and has a capacity equal to that of 24 Olympic swimming pools (Hernández and Morote, 2019). In the Region of Murcia, four storm tanks of the twenty-one projected for the Mar Menor have been built in the last two years, as part of the project "Vertido Cero" (García et al., 2017).

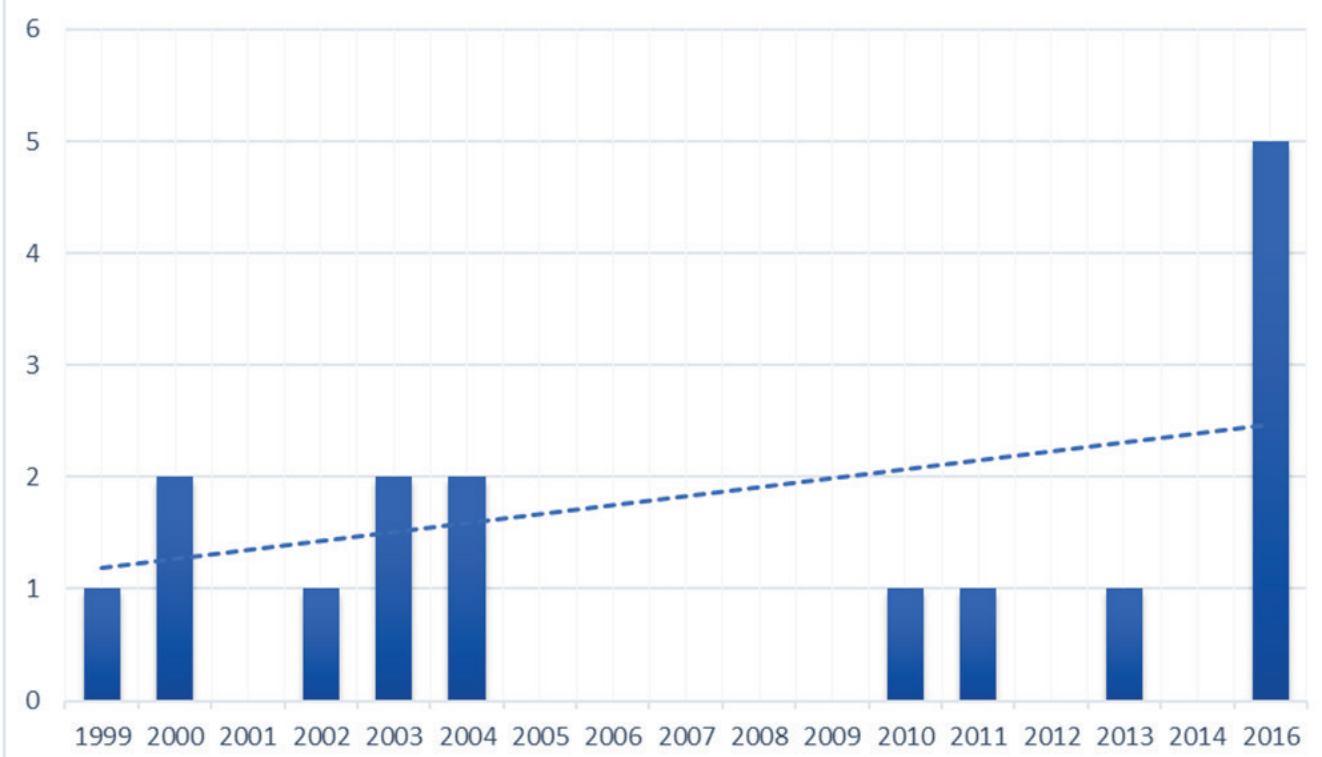

Figure 8. Evolution of the construction of storm tanks (Source: Own elaboration). 


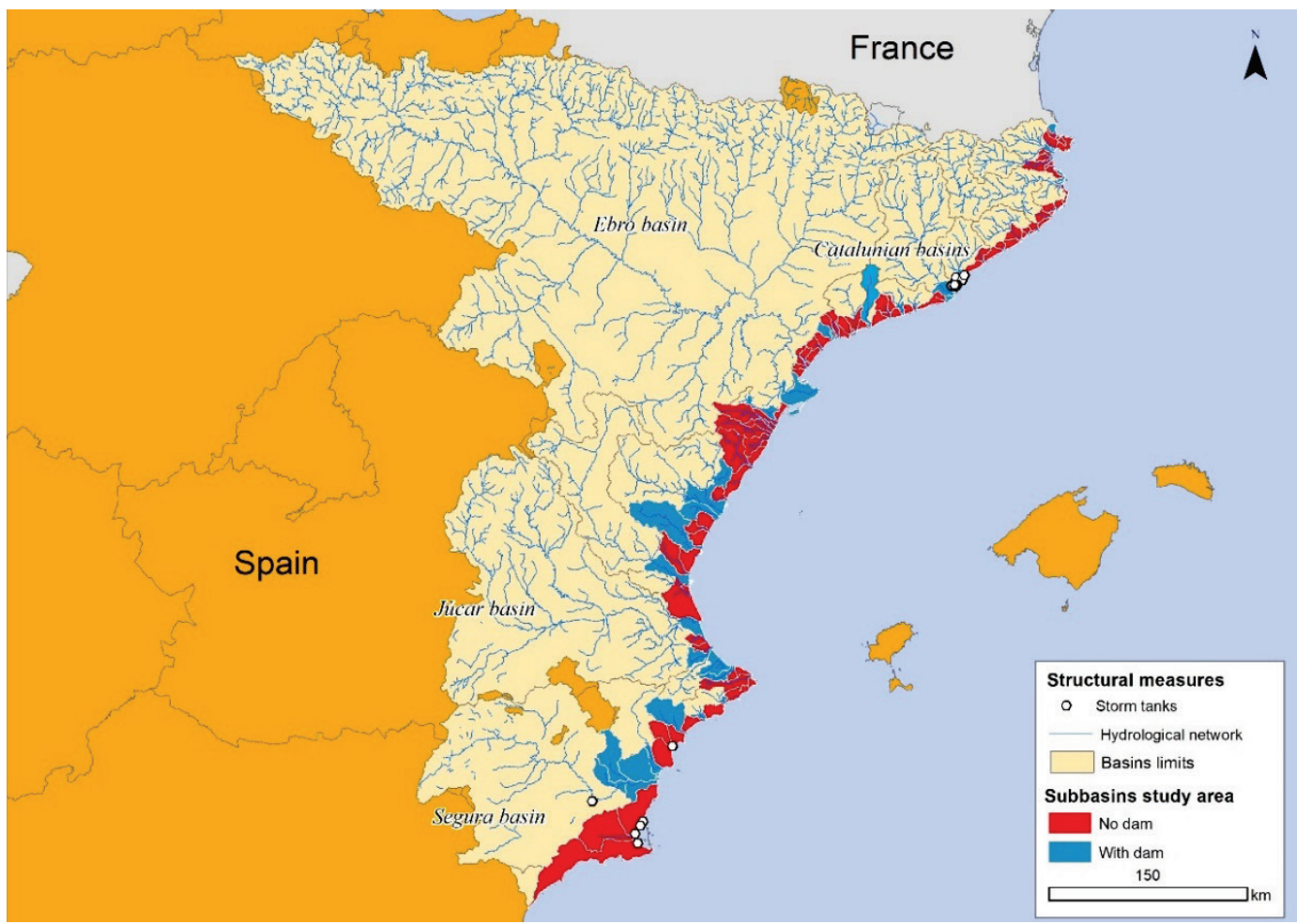

Figure 9. Storm tanks distribution map (Source: Own elaboration).

\subsection{Evidence for the persistence of the "escalator effect" in the study area}

The socioeconomic changes experienced in the last four decades in Spain have had a special impact on the land and, therefore, on its exposure to natural hazards (Barredo et al., 2012). This process has been especially intense and marked in the littoral area, where recent urban growth linked to urbantourist development has been described as a true "urbanizing tsunami" (Gaja, 2008). According to the results of Figure 10, since 1975 the urbanized area and the number of buildings that occupy each of the flood zones for the return periods studied $(10,50,100$, and 500 years) have undergone a continuous accumulated growth on the coast of the provinces of Murcia and Alicante.

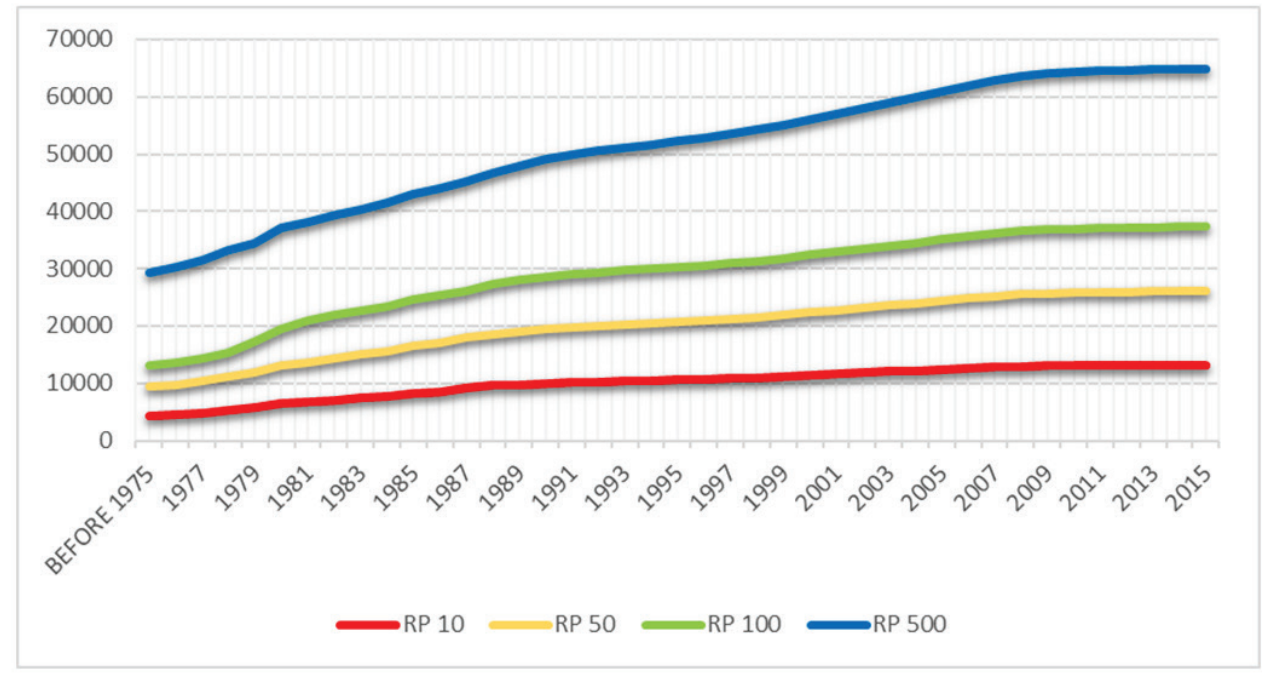

Figure 10. Evolution of the number of buildings built in each of the return periods areas (1975-2016) (Source: Own elaboration). 
In relative terms, the results are truly alarming. For the period analyzed, the increase in urban parcels was $347 \%(<1975=100)$, which represents an annual growth rate of $8.9 \%$. However, it is striking that the growth of urban parcels in areas prone to flooding has been greater than in safe areas $(273 \%)$.

As can be deduced from the previous data, the regulation of floodplains in the study area has been conspicuous by its absence or its limited effectiveness (López et al., 2020 and Ribas et al., 2020). According to the works consulted in this regard, in recent decades floodplain management policy have not stopped the occupation of flood prone areas in the study area (Pérez-Morales et al., 2015) except in those areas where the delimitation of the Domain Public Hydraulic was made (Olcina-Cantos, 2007) or by the presence of a continuous flow. According with the last, in the present work we wish to determine if this practically incessant trend has been homogeneous across all the basins of the study area or, on the contrary, there are differences between those regulated by dams and those that are not, due to the "escalator effect".

The results obtained partially validate this hypothesis (Table 2). There is a statistically significant difference ( $\mathrm{p}$-value $<0.05$ ) in the proportion of buildings built in the most probable flood zone of the four analyzed, that of RP10, between the sub-basins with and without a dam. In the rest (RP50, RP100, and RP500), the percentage of buildings erected in floodplain areas in unregulated basins with dams is higher than in those without a dam ( $p$-value $>0.05$ ). In other words, there is a progressive occupation of potentially floodable areas in the zones closest to the riverbed.

Table 2. Inferential statistics of real estate activity in basins with and without a dam in the study area (Source: Own elaboration).

\begin{tabular}{|l|c|c|c|c|c|}
\hline $\begin{array}{c}\text { Return } \\
\text { period }\end{array}$ & $\begin{array}{c}\text { No. cadastral } \\
\text { parcels built in } \\
\text { flood prone areas } \\
\text { in a subbasin with } \\
\text { a dam }\end{array}$ & $\begin{array}{c}\% \\
(100=\text { Cadastral } \\
\text { parcels in areas } \\
\text { not prone to } \\
\text { flooding })\end{array}$ & $\begin{array}{c}\text { No. cadastral } \\
\text { parcels built in } \\
\text { flood prone areas in } \\
\text { a subbasinwithout a } \\
\text { dam }\end{array}$ & $\begin{array}{c}\%(100=\text { Cadastral } \\
\text { parcels in areas not } \\
\text { prone to flooding })\end{array}$ & $\begin{array}{c}\text { p- } \\
\text { value } \\
(0.05)\end{array}$ \\
\hline RP10 & 18199 & 4.4 & 4905 & 3.7 & $0.032^{*}$ \\
\hline RP50 & 26556 & 6.4 & 6756 & 5.4 & 0.138 \\
\hline RP100 & 42316 & 10.2 & 14678 & 11.3 & 0.509 \\
\hline RP500 & 49099 & 11.9 & 19935 & 15.4 & 0.900 \\
\hline
\end{tabular}

To reinforce the above evidence, the percentage increases in the buildings built in basins regulated and not regulated by dams -from 1975 to the present - were compared, regardless of whether or not they were built in a flood zone. The year 1975 was taken for two fundamental reasons: regardless of the year of construction of the dam, the precision of the data from the cadastral source is greater thereafter (García Martín, 2013) and, above all, because it marks the start of the major processes of occupation of the coastline in Spain (Pérez-Morales et al., 2015). According to the data commented on above, the contrast between the percentage increase in what was built between basins with a dam and those without a dam does not allow us to confirm the hypothesis ( $\mathrm{p}$-value $<0.05$ ). However, a higher mean growth $(140.3 \%$ without a dam versus $156.1 \%)$ and median $(104.6 \%$ without a dam versus and $145.6 \%$ with a dam) is observed in hydrographic basins where there is a reservoir to protect downstream areas (Fig. 11). 


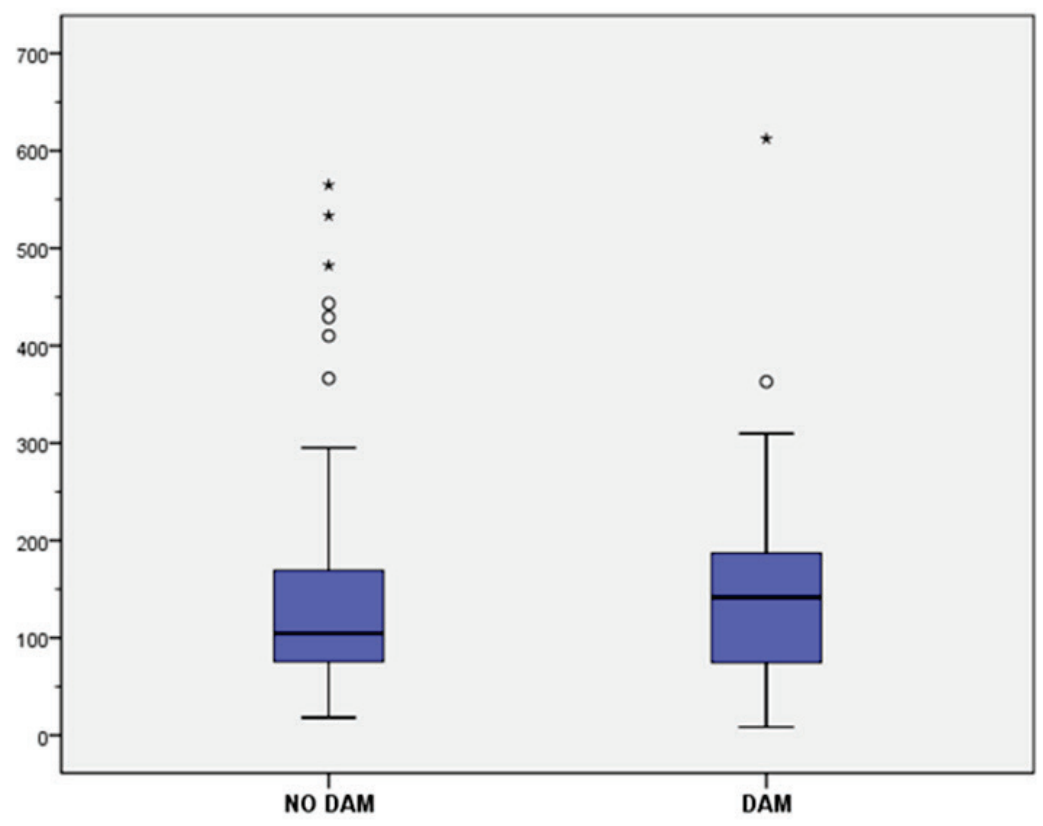

Figure 11. Boxplot showing percentage increase in cadastral plots in sub-basins with and without a dam (1975-2015) (Source: Own elaboration).

\section{Conclusions}

Structural measures have not stopped growing in number and size in the study area. Throughout the 20th century and up to the present, an ascending trend line can be seen. In that trend two phases of growth can be observed. In the first half of the century, the actions were mainly limited to dams and reservoirs capable of regulating channels, to supply a growing population with water resources and defend it from flood waves. In the second half of the century, this population increase, which had been making greater demands in terms of space and water for both agricultural and urban use, accelerated the progressive occupation of the riverbeds with the consequent increase in flood events and associated economic losses. At this point large supply projects ceased to be important due to, among other reasons, a lack of space for the location of profitable dams. Meanwhile, the necessary debate on the convenience between preventive and structural measures began, channeling gaining in importance as an immediate and more economical solution to solve the increased exposure to the increasingly frequent floods. More recently, storm tanks have complemented the work of such channeling. It is possible that the importance of storm tanks will be greater in the future due to the advantages that they offer, namely: defense against floods, purification of contaminated water, and its subsequent use as non-potable water.

A plausible explanation for this type of cognitive dissonance of the population when occupying floodplains, despite its negative consequences, seems to be given by the "escalator effect". The results obtained in the study area allow this hypothesis to be partially validated, since only in the floodplain area with the highest probability of occurrence of flooding (RP10) has urban growth (p-value $<0.05$ ) been greater in watersheds with a dam than in those without. To consolidate this confirmatory finding, the percentage increases from 1975 to the present in the urban growth in basins regulated and not regulated by dams were compared, regardless of whether or not they were built in a floodplain. The result is not clear in terms of statistical significance ( $p$-value $>0.05$ ), but the percentage growth is higher in basins with a dam than in those without one. In this sense, our results are consistent with Collenteur et al. (2015).

The fact that the results in the study area are not entirely conclusive could be due to two main reasons: firstly, the natural characteristics of the channels analyzed and, secondly, the differences in behavior between urban typologies of the population centers. The riverbeds are mostly represented by 
ephemeral channels which, lacking a continuous flow and if not delimited, easily become ideal land for use in basins both with and without regulation. Quite a different situation exists when the flow is continuous and the space occupied by a river module is physically recognized. In these cases, the spatial differentiation between basins, in order to carry out the contrast, is simpler, as seems to be the case in the areas analyzed by Parker (1995). With regard to the populations of the study area, there are at least three types of urban nuclei with different construction trends: regional and provincial capitals, mediumsized cities, and populations of less than 50,000 inhabitants. This urban heterogeneity represents an added difficulty when establishing a generalization and a comparison of basins, since the construction trends of the populations tend to be very divergent from each other.

\section{Acknowledgement}

This work was supported by the research project 20912/PI/18, financed by "Fundación SénecaAgencia de Ciencia y Tecnología de la Región de Murcia (Spain)”.

\section{References}

Andrés-Doménech, I., Montanari, A., Marco, J.B. 2012. Efficiency of storm detention tanks for urban drainage systems under climate variability. Journal of Water Resources Planning and Management 138 (1), 3646. https://doi.org/10.1061/(ASCE)WR.1943-5452.0000144

Añó Vidal, C., Pascual Aguilar, J.A., Sánchez Díaz, J. 2005. Capacidad de uso y sellado antropogénico del suelo en la franja litoral de la provincia de Castellón. Investigaciones Geográficas 38, 65-77.

Ayala, F.J., Olcina-Cantos, J. 2002. Riesgos naturales. Editorial Ariel. Barcelona.

Ayesa, A. 2016. Tanques de Tormenta. Informe. Hidrostank. http://observatoriaigua.uib.es/repositori/suds_hidrostank_tanques.pdf

Barredo, J.I., Saurí Pujol, D., Llasat Botija, M.D.C. 2012. Assessing trends in insured losses from floods in Spain 1971-2008. Natural Hazards and Earth System Sciences 12, 1723-1729. https://doi.org/10.5194/nhess$12-1723-2012$

Berga, L. 1997. Los embalses en la laminación de avenidas en España. Revista de Obras Públicas 3371, 155-167.

Berga, L. 2003. Presas y embalses en la España del siglo XX. Revista de Obras Públicas 3438, 37-40.

Berz, G., Kron, W., Loster, T., Rauch, E., Schimetschek, J., Schmieder, J., Siebert, A., Smolka, A., Wirtz, A. 2001. World map of natural hazards-a global view of the distribution and intensity of significant exposures. Natural Hazards 23 (2-3), 443-465. https://doi.org/10.1023/A:1011193724026

BOE (Boletín Oficial del Estado-Gobierno de España). 1988. Real Decreto 927/1988, de 29 de julio, por el que se aprueba el Reglamento de la Administración Pública del Agua y de la Planificación Hidrológica, en desarrollo de los títulos II y III de la Ley de Aguas. Ministerio de Obras Públicas y Urbanismo

Burby, R.J. 2006. Hurricane Katrina and the paradoxes of government disaster policy: Bringing about wise governmental decisions for hazardous areas. The Annals of the American Academy of Political and Social Science 604 (1), 171-191. https://doi.org/10.1177/0002716205284676

Calvo García-Tornel, F. Granell Pérez, M.C. 2009. Valoración social del riesgo por inundación en el litoral meridional de la Región de Murcia. Scripta Nova. Revista Electrónica de Geografia y Ciencias Sociales. 13 (295).

Carmona, P., Ruiz, J.M. 2000. Las inundaciones de los ríos Júcar y Turia. Serie Geográfica 9, 49-69.

Castejón-Porcel, G., Romero-Díaz, A. 2014. Inundaciones en la Región de Murcia en los inicios del siglo XXI. Biblio 3WRevista Bibliográfica de Geografia y Ciencias Sociales 19 (1102), 1-40.

Castro Fresno, D., Rodríguez Bayón, J., Rodríguez Hernández, J., Ballester Muñoz, F. 2005. Sistemas urbanos de drenaje sostenible (SUDS). Interciencia 30 (5), 255-260. 
Collenteur, R.A., de Moel, H., Jongman, B., Di Baldassarre, G. 2015. The failed-levee effect: Do societies learn from flood disasters? Natural Hazards 76 (1), 373-388. https://doi.org/10.1007/s11069-014-1496-6

Confederación Hidrográfica del Segura. 2007. Catálogo de actuaciones del plan de defensa frente a inundaciones en la cuenca del Segura: XX aniversario: Real Decreto-Ley 4/1987, de 13 de noviembre.

Confederación Hidrográficas del Júcar. 1997. Plan Hidrológico del Júcar, Catálogo de actuaciones.

Consorcio de Compensación de Seguros (CCS). 2018. Estadística de riesgos extraordinarios, Serie 1971-2018, Madrid.

Córdova, J.Y. 2008. Evolución de las presas en España. Revista de Obras Públicas: Órgano Profesional de los Ingenieros de Caminos, Canales y Puertos 3493, 73-88.

Dios, R.J.L. 2008. Las presas y la «Revista de Obras Públicas». Revista de Obras Públicas 3493, 59-66.

Djalante, R. 2019. Key assessments from the IPCC special report on global warming of $1.5^{\circ} \mathrm{C}$ and the implications for the Sendai framework for disaster risk reduction. Progress in Disaster Science, 1, 100001. https://doi.org/10.1016/j.pdisas.2019.100001

Gago, M.A. 2010. Depósitos de tormenta y balsas de laminación en el Área Metropolitana de Barcelona. Cimbra: Revista del Colegio de Ingenieros Técnicos de Obras Públicas 392, 54-61.

Gaja, F. 2008. El "tsunami urbanizador" en el litoral mediterráneo. El ciclo de hiperproducción inmobiliaria 19962006. Scripta Nova: Revista Electrónica de Geografía y Ciencias Sociales 12.

Galloway G. 2004. Integrated flood management, case study, USA: flood management - Mississippi River. WMO/GWP Associated Programme on Flood Management.

García Martín, F. 2013. Una metodología para la delimitación y clasificación de las formas urbanas en las ciudades intermedias españolas durante el siglo XX basada en SIG. V Seminario Internacional de Investigación en Urbanismo, Barcelona-Buenos Aires, junio 2013 (pp. 1199-1215). Departament d'Urbanisme i Ordenació del Territori. Universitat Politècnica de Catalunya, Barcelona.

García, J.T., Espín-Leal, P., Vigueras-Rodriguez, A., Castillo, L.G., Carrillo, J.M., Martínez-Solano, P. D., Nevado-Santos, S. 2017. Urban runoff characteristics in combined sewer overflows (CSOs): analysis of storm events in southeastern spain. Water 9 (5), 303. https://doi.org/10.3390/w9050303

Generalitat de Catalunya (GC) 2010. Plan de emergencia especial por inundaciones (INUNCAT). Generalitat de Catalunya.

Generalitat Valenciana (GV) 2003. Plan de Acción Territorial de carácter sectorial sobre prevención del Riesgo de Inundación en la Comunidad Valenciana, PATRICOVA. Valencia, 12, 2011.

Gil Olcina, A. 1992. Desequilibrios hidrográficos en España y trasvases a la vertiente mediterránea: utopías y realizaciones. Investigaciones Geográficas 10, 7-24.

Gil Olcina, A. 2002. La polémica decimonónica sobre los pantanos. Estudios Geográficos, 63 (248-249), 675-694.

Gil-Guirado, S., Lopez-Martinez, F. 2019. SMC-Flood database: a high-resolution press database on flood cases for the Spanish Mediterranean coast (1960-2015). Natural Hazards and Earth System Sciences 19 (9), 1955-1955. https://doi.org/10.5194/nhess-19-1955-2019

Giménez Ferrer, J.M. 2003. Riesgo de inundación y ordenación urbana en el litoral meridional alicantino. Publicaciones de la Universidad de Alicante, Alicante, 352 pág.

Grindlay, A., Hernández, E. 2007. Las infraestructuras hidráulicas en la cuenca del Segura. Actas del V Congreso Nacional de la Ingeniería Civil, Desarrollo y Sostenibilidad en el Marco de la Ingeniería. Sevilla, 26-28 de noviembre. Ed. Colegio de Ingenieros de Caminos, Canales y Puertos, 15 p.

Hernández, M., Morote, A. F. 2019. The use of rainwater in Alicante (southeast Spain). A new urban approach to urban water management. UPLanD 4 (1), 53-66. https://doi.org/10.6092/2531-9906/6113

Jonkman, S.N. 2005. Global perspectives on loss of human life caused by floods. Natural Hazards 34 (2), 151175.

Lane, S.N., Odoni, N., Landström, C., Whatmore, S.J., Ward, N., Bradley, S. 2011. Doing flood risk science differently: an experiment in radical scientific method. Transactions of the Institute of British Geographers 36 (1), 15-36. https://doi.org/10.1111/j.1475-5661.2010.00410.x 
Lemeunier, G., Picazo, M.T. 1988. La sociedad murciana frente a las inundaciones (1450-1900). In A. Gil Olcina, A. Morales Gil (Dir.). Avenidas fluviales e inundaciones en la cuenca del mediterráneo. Universidad de Alicante, Instituto Interuniversitario de Geografía, pp. 365-373, Alicante.

Lessard, P., Beck, M.B. 1991. Dynamic simulation of storm tanks. Water Research 25 (4), $375-391$. https://doi.org/10.1016/0043-1354(91)90074-Z

Llasat, M.C., Barriendos, M., Barrera, A., Rigo, T. 2005. Floods in Catalonia (NE Spain) since the 14th century. Climatological and meteorological aspects from historical documentary sources and old instrumental records. Journal of Hydrology 313 (1-2), 32-47. https://doi.org/10.1016/j.jhydrol.2005.02.004

López-Martínez, F., Pérez-Morales, A., Illán-Fernández, E.J. 2020. Are local administrations really in charge of flood risk management governance? The Spanish Mediterranean coastline and its institutional vulnerability issues. Journal of Environmental Planning and Management 63 (2), 257-274. https://doi.org/10.1080/09640568.2019.1577551

MAGRAMA 2015. Inventario de presas y embalses. Recuperado de https://www.miteco.gob.es

Marco Segura, J.B. 2012. Los proyectos de regulación de los ríos Júcar y Turia (1928-1964). Una nueva lectura. Cuadernos de Geografia 91, 73-94.

Mateu Bellés, J.F. 1990. Avenidas y riesgos de inundación en los sistemas fluviales mediterráneos de la Península Ibérica. Boletín de la Asociación de Geógrafos Españoles 10, 45-86.

Melgarejo Moreno, J. 2002. Política de aguas y modelos territoriales en el Sureste Peninsular. Actas del III Congreso Ibérico sobre Gestión y Planificación del Agua. Fundación Nueva Cultura del Agua, Sevilla, $18 \mathrm{pp}$.

MHAP. Dirección General del Catastro. Visited on $5^{\text {th }}$ August 2020, Dirección General del Catastro: http://www.sedecatastro.gob.es/

Montz, B., Gruntfest, E.C. 1986. Changes in American urban floodplain occupancy since 1958: the experiences of nine cities. Applied Geography 6 (4), 325-338. https://doi.org/10.1016/0143-6228(86)90034-2

Olcina-Cantos, J. 2004. Riesgo de inundaciones y ordenación del territorio en la escala local. El papel del planeamiento urbano municipal. Boletín de la Asociación de Geógrafos Españoles 37, 49-84.

Olcina-Cantos, J. 2007. Riesgo de inundaciones y ordenación del territorio en España. La consideración del peligro de inundaciones en los procesos de planificación territorial. Fundación Instituto Euromediterráneo del Agua, Alicante.

Olcina-Cantos, J., Rico Amorós, A.M. 2000. Estudios sobre lluvias torrenciales e inundaciones en la provincia de Alicante (1982-1999). Serie Geográfica 9, 71-93.

Olcina-Cantos, J., Sauri, D., Hernández, M., Ribas, A. 2016. Flood policy in Spain: a review for the period 19832013. Disaster Prevention and Management, 25(1), 41-58. https://doi.org/10.1108/DPM-05-2015-0108

Parker, D.J. 1995. Floodplain development policy in England and Wales. Applied Geography 15 (4), 341-363. https://doi.org/10.1016/0143-6228(95)00016-W

Parker, D., Tapsell, S. 2009. Relations between different types of social and economic vulnerability. Final draft report submitted to EU project "Enhancing resilience of communities and territories facing natural and na-tech hazards”, ENSURE Deliverable 2.1, 89 pp.

Pérez-Morales, A. 2008. Aumento del riesgo de inundación por ocupación indebida de las áreas de convergencia de aguas en el Sur de la Región de Murcia. Scripta Nova: Revista Electrónica de Geografía y Ciencias sociales $12,23$.

Pérez-Morales, A. 2009. Riesgo de inundación y politicas sobre el territorio en el sur de la Región de Murcia. Tesis Doctoral. Universidad de Murcia

Pérez-Morales, A. 2010. Actuaciones de carácter estructural para la mitigación y prevención de los efectos de las riadas e inundaciones en los municipios del sur de la Región de Murcia. Boletín de la Asociación de Geógrafos Españoles 53, 267-285.

Pérez-Morales, A., Gil-Guirado, S., Olcina-Cantos, J., 2015. Housing bubbles and the increase of flood exposure. Failures in flood risk management on the Spanish south-eastern coast (1975-2013). Journal of Flood Risk Management 11, S302-S313. https://doi.org/10.1111/jfr3.12207 
Pérez-Morales, A., Romero Díaz, A., Caballero Pedraza, A., 2016. The Urbanisation Process and its Influence on the Increase in Flooding (Region of Murcia, Campo de Cartagena-Mar Menor, South-east Spain). In Crisis, globalizations and social and regional imbalances in Spain. International Geographical Unión (UGI), Asociación de Geógrafos españolas (AGE), 92-103.

Pérez-Morales, A., Gil-Guirado, F., Martín, F.M.G., 2015. Veinte años de protección de cauces en el litoral de la Región de Murcia (1194-2014). Evaluación de la eficiencia de las medidas de Ordenación del Territorio. Anales de Geografia de la Universidad Complutense 35 (1), 169-185.

Perni, A., Martínez-Paz, J.M. 2013. A participatory approach for selecting cost-effective measures in the WFD context: the Mar Menor (SE Spain). Science of the Total Environment 458, 303-311. https://doi.org/10.1016/j.scitotenv.2013.04.029

Quereda Sala, J.J. 2000. La evolución de las precipitaciones en la cuenca occidental del mediterráneo: ¿Tendencia o ciclos? Investigaciones Geográficas 24, 17-35.

Quevedo, A.T. 1963. Causas meteorológicas de las inundaciones de septiembre de 1962 en el Bajo Vallés, Llano de Llobregat y la Maresma. Estudios Geográficos 24 (91), 137.

Ribas, A., Olcina, J., Sauri, D. 2020. More exposed but also more vulnerable? Climate change, high intensity precipitation events and flooding in Mediterranean Spain. Disaster Prevention and Management 29 (3), 229-248. https://doi.org/10.1108/DPM-05-2019-0149

Romero Díaz. A., Maurandi Guirado, A. 2000. Las inundaciones en la cuenca del Segura en las dos últimas décadas del siglo xx. Actuaciones de prevención. Serie Geográfica 9, 93-120.

Roset-Pagès, D., Saurí, D., Ribas, A. 1999. Las obras hidráulicas en los sistemas fluviales de la Costa Brava: preferencias locales y limitaciones de un modelo convencional de adaptación al riesgo de inundación. Investigaciones Geográficas 22, 79-93.

Saurí, D., Ribas, A., Lara, A., Pavón, D. 2010. La percepción del riesgo de inundación: experiencias de aprendizaje en la Costa Brava. Papeles de Geografía 51-52, 269-278.

Saurí, D., Roset-Pagès, D., Ribas-Palom, A., Pujol-Caussa, P. 2001. The 'escalator effect' in flood policy: the case of the Costa Brava, Catalonia, Spain. Applied Geography 21 (2), 127-143. https://doi.org/10.1016/S01436228(01)00003-0

Smith, K., Petley, D. N. 2009. Environmental Hazards. Assessing riks and reducing disaster. Routledge, $5^{\mathrm{a}}$ ed., London, $414 \mathrm{p}$.

SEPREM (Sociedad de Presas y Embalses). 2015. Inventario de presas. http://www.seprem.es/presases.php

Tariq, M.A.U.R., Van De Giesen, N. 2012. Floods and flood management in Pakistan. Physics and Chemistry of the Earth, Parts A/B/C 47-48, 11-20. https://doi.org/10.1016/j.pce.2011.08.014

Valera Lozano, A., Añó Vidal, C., Sánchez Díaz, J. 2011. Urban growth (1956-1998) in the metropolitan area of Alacant-Elx (Comunitat Valenciana). Boletín de la Asociación de Geógrafos Españoles 44, 169-186.

Vera-Rebollo, J.F. 2005. El auge de la función residencial en destinos turísticos del litoral mediterráneo: entre el crecimiento y la renovación. Papers de Turisme 37-38, 95-114.

Wesselink, A. J. 2007. Flood safety in the Netherlands: the Dutch response to Hurricane Katrina. Technology in Society 29 (2), 239-247. https://doi.org/10.1016/j.techsoc.2007.01.010

White, G. F. 1958. Changes in urban occupance of flood plains in the United States (Vol. 57). University of Chicago, Chicago.

White, G. F. 1973. Natural Hazards Research. In: R.J. Chorley (Ed.), Directions in Geography, Metheun \& Co. Ltd., pp. 193-216, London. 